AGRARIS: Journal of Agribusiness and Rural Development Research

Vol. 7 No. 1 January - June 2021, Pages: 24-35

Article history:

Submitted: December $4^{\text {th }}, 2020$

Accepted: January $14^{\text {th }}, 2021$
Mark Buda* and Zainalabidin Mohamed

Department of Agribusiness and Bioresource Economics, Faculty of Agriculture, Universiti Putra Malaysia, 43400 UPM Serdang, Selangor, Malaysia

*) Correspondence email: markbuda@upm.edu.my

\title{
Impact of Different Importation Policies Scenarios on Beef Industry in Peninsular Malaysia
}

\author{
DOI: https://doi.org/10.18196/agraris.v7i1.10540
}

\begin{abstract}
The supply side of beef industry has not responded well to the rising demand for beef. This industry is still highly dependent on imported beef and feeder cattle for beef production to meet the local demand. The objective of this study is to analyse the impacts of different importation policy scenarios on beef industry in Peninsular Malaysia. A simulation model that based on estimated market model is used to analyse the policy. The findings imply that the number of import cattle for breeding (ICTB) should be maintained, while import of cattle for slaughter or feeder cattle should be increased by $20 \%$. This will improve beef self-sufficiency level while stabilizing beef retail price.
\end{abstract}

Keywords: beef industry, cattle importation, market model, policy simulation

\section{INTRODUCTION}

Beef industry is highly dependent on importation to deal with excess demand for beef. The importations are in the forms of live animal (cattle and buffalo) and processed meat. The imported live animals are used for slaughter or as feeder animals or for breeding purposes. The main volume of the importation usually is animal for slaughter. Table 1 presents the live animal imports for the period of 1971-1975 to 2011-2015. During those periods, import of cattle for slaughter increased from 1,188 heads to 77,901 heads, while import of cattle for breeding increased from 1,566 heads to 32,621 heads. Import of buffalo for slaughter increased from 411 heads to 1,516 and import of buffalo for breeding increased from 494 heads to 1,188 heads, during the same periods.

TABLE 1. AVERAGE LIVE ANIMAL IMPORTS OF CATTLE AND BUFFALO IN PENINSULAR MALAYSIA, 1971 - 1975 T0 2011 - 2015 (HEADS)

\begin{tabular}{ccccc}
\hline Year & Cattle for Breeding (Heads) & Cattle for Slaughter (Heads) & Buffalo for Breeding (Heads) & Buffalo for Slaughter (Heads) \\
\hline $1971-1975$ & 1,566 & 1,188 & 494 & 411 \\
$1976-1980$ & 5,021 & 5,263 & 151 & 150 \\
$1981-1985$ & 6,818 & 6,529 & 251 & 299 \\
$1986-1990$ & 1,719 & 2,121 & 99 & 215 \\
$1991-1995$ & 13,792 & 13,377 & 638 & 2,451 \\
$1996-2000$ & 41,593 & 25,901 & 357 & 2,148 \\
$2001-2005$ & 21,085 & 53,808 & 711 & 1,361 \\
$2006-2010$ & 22,170 & 59,803 & 103 & 2,039 \\
$2011-2015$ & 32,621 & 77,901 & 1,188 & 1,516
\end{tabular}

Sources: Department of Veterinary Services (1970-1998), Department of Veterinary Services (2011), Department of Veterinary Services (2012), and Department of Veterinary Services (2019) 
Table 2 shows import of beef for the period of 1971-1975 to 2011-2015. Import of beef increased from 1,436 MT during the period of 1971-1975 to 151,689 MT during the period of 2011-2015. Despite an increasing amount, the growth rate of beef import is slowing down from $34.86 \%$ to $9.26 \%$.

TABLE 2. AVERAGE IMPORT AND AVERAGE ANNUAL IMPORT GROWTH RATE OF BEEF IN PENINSULAR MALAYSIA, 1971 - 1975 TO 2011 - 2015 (MT \& \%)

\begin{tabular}{ccc}
\hline Year & Beef Import (MT) & Growth (\%) \\
\hline $1971-1975$ & 1,436 & 34.86 \\
$1976-1980$ & 7,081 & 21.08 \\
$1981-1985$ & 11,820 & 36.34 \\
$1986-1990$ & 28,800 & 17.41 \\
$1991-1995$ & 52,427 & 8.09 \\
$1996-2000$ & 69,353 & 5.52 \\
$2001-2005$ & 96,133 & 8.11 \\
$2006-2010$ & 103,956 & 0.41 \\
$2011-2015$ & 151,689 & 9.26 \\
\hline
\end{tabular}

Sources: Department of Veterinary Services (1970-1998), Department of Veterinary Services (2011), Department of Veterinary Services (2012), and Department of Veterinary Services (2019)

In term of local beef production, the beef animal population are still far below to provide sufficient number of animals for slaughter. The population growth rate is slow compared to growth rate of demand for slaughtered beef animal. Table 3 presents the beef animal population from $1971-1975$ periods to $2011-2015$ periods. During these periods, total beef animal population increased from 552,517 heads to 733,778 heads. Beef cattle constitute more than $50 \%$ of beef animal population with an increased share of $50.44 \%$ during the period of 1971-1975 to $86.65 \%$ during the period of 2011-2015. Although the share of beef cattle to total beef animal population increased together with its population, the growth rate of beef cattle population is showing a declining trend. The growth rate of beef cattle population used to be $5.59 \%$ during the period of $1971-1975$, but the rate was only $0.91 \%$ during the period of $2006-2010$ and became negative $(-2.86 \%)$ during the period of 2011 2015. For dairy cattle, the population number and share to total cattle population show a declining trend. The dairy cattle population growth rate was negative during the period of 1986-1990 to the period of 2001-2005. The same situation happened with buffalo population and share to total cattle animal population as it showed a declining trend with negative growth rate for the past forty-five years.

Basically, beef animal slaughtered for its meat are beef cattle, buffalo and some culled dairy cattle. Approximately, only $7 \%$ of beef production in the last forty-five years came from buffalo and culled dairy cattle. As can be seen in Table 4, recorded cattle slaughtered during the period of 1971-1975 to the period of 1996-2000 showed an increasing trend of beef cattle animal. The number of cattle slaughtered increased from 50,052 heads to 112,340 heads during that period. During the period of 2001-2005 and the period of 2006-2010, the number of recorded cattle slaughtered decreased from 102,417 heads and 101,679 heads. The number increased to 127,397 heads during the period of 2011-2015. Based on this recorded number, the extraction rate from beef cattle population was within $13 \%$ to $21 \%$ for the past forty-five 
years. The period of 2011-2015 recorded the highest extraction rate of $20.04 \%$ and the period of $1986-1990$ recorded the lowest extraction rate of $13.84 \%$.

TABLE 3. AVERAGE POPULATION AND AVERAGE ANNUAL POPULATION GROWTH RATE OF BEEF CATLE, DAIRY CATLE, AND BUFFALO IN PENINSULAR MALAYSIA, 1971 - 1975 TO 2011 - 2015 (HEADS \& \%)

\begin{tabular}{crrrrrrrrrr}
\hline Year & $\begin{array}{r}\text { Beef Cattle } \\
\text { (Heads) }\end{array}$ & $\begin{array}{r}\text { \% from } \\
\text { Beef } \\
\text { Animal }\end{array}$ & $\begin{array}{r}\text { Growth } \\
\text { (\%) }\end{array}$ & $\begin{array}{r}\text { Dairy } \\
\text { Cattle } \\
\text { (Heads) }\end{array}$ & $\begin{array}{r}\text { \% from } \\
\text { Beef } \\
\text { Animal }\end{array}$ & $\begin{array}{r}\text { Growth } \\
\text { (\%) }\end{array}$ & $\begin{array}{r}\text { Buffalo } \\
\text { (Heads) }\end{array}$ & $\begin{array}{r}\text { \% from Beef } \\
\text { Animal }\end{array}$ & $\begin{array}{r}\text { Growth } \\
\text { (\%) }\end{array}$ & $\begin{array}{r}\text { Total Beef } \\
\text { Animal } \\
\text { (Heads) }\end{array}$ \\
\hline $1971-1975$ & 278,699 & 50.44 & 5.59 & 66,345 & 12.01 & 1.79 & 207,472 & 37.55 & -1.71 & 552,517 \\
$1976-1980$ & 366,107 & 55.93 & 3.99 & 81,752 & 12.49 & 8.93 & 206,720 & 31.58 & -1.07 & 654,579 \\
$1981-1985$ & 427,597 & 61.24 & 3.49 & 100,171 & 14.35 & 0.24 & 170,501 & 24.42 & -3.80 & 698,268 \\
$1986-1990$ & 479,562 & 66.85 & 2.31 & 99,384 & 13.85 & -1.30 & 138,420 & 19.30 & -4.40 & 717,366 \\
$1991-1995$ & 564,149 & 75.07 & 2.62 & 74,821 & 9.96 & -5.90 & 112,527 & 14.97 & -4.71 & 751,497 \\
$1996-2000$ & 591,108 & 80.79 & 2.39 & 49,002 & 6.70 & -9.92 & 91,557 & 12.51 & -2.65 & 731,667 \\
$2001-2005$ & 671,455 & 85.40 & 1.56 & 33,308 & 4.24 & -3.25 & 81,454 & 10.36 & -1.92 & 786,217 \\
$2006-2010$ & 732,939 & 86.93 & 0.91 & 32,682 & 3.88 & 1.55 & 77,483 & 9.19 & -1.71 & 843,103 \\
$2011-2015$ & 635,789 & 86.65 & -2.86 & 33,471 & 4.56 & 0.02 & 64,517 & 8.79 & -3.72 & 733,778 \\
\hline
\end{tabular}

Sources: Department of Veterinary Services (1970-1998), Department of Veterinary Services (1999-2009), and Department of Veterinary Services (2019)

The slaughtered number of buffalo was on a decreasing trend. As can be seen in Table 4, the number of recorded buffalo slaughtered during the period of 1971-1975 to the period of 2011-2015 decreased from 34,859 heads to 8,257 heads. The extraction rate used to be $16.80 \%$ during the period of $1971-1975$ compared to the extraction rate during the period of 2011-2015 which was only $12.80 \%$.

TABLE 4. AVERAGE RECORDED SLAUGHTERED AND THEIR EXTRACTION RATES OF CATLE BUFFALO IN PENINSULAR MALAYSIA, 1971 - 1975 TO 2011 - 2015 (HEADS AND \%)

\begin{tabular}{ccccc}
\hline Year & $\begin{array}{c}\text { Recorded Cattle } \\
\text { Slaughtered (Heads) }\end{array}$ & $\begin{array}{c}\text { Extraction Rates from Beef } \\
\text { Cattle Population (\%) }\end{array}$ & $\begin{array}{c}\text { Recorded Buffalo } \\
\text { Slaughtered (Heads) }\end{array}$ & $\begin{array}{c}\text { Extraction Rates from } \\
\text { Buffalo Population (\%) }\end{array}$ \\
\hline $1971-1975$ & 50,052 & 17.96 & 34,859 & 16.80 \\
$1976-1980$ & 55,005 & 15.02 & 29,051 & 14.05 \\
$1981-1985$ & 66,838 & 15.63 & 23,786 & 13.95 \\
$1986-1990$ & 66,353 & 13.84 & 16,253 & 11.74 \\
$1991-1995$ & 85,754 & 15.20 & 17,113 & 15.21 \\
$1996-2000$ & 112,340 & 19.01 & 15,997 & 17.47 \\
$2001-2005$ & 102,417 & 15.25 & 10,800 & 13.26 \\
$2006-2010$ & 101,679 & 13.87 & 10,333 & 13.34 \\
$2011-2015$ & 127,397 & 20.04 & 8,257 & 12.80 \\
\hline
\end{tabular}

Sources: Department of Veterinary Services (1970-1998), Department of Veterinary Services (1999-2009), and Department of Veterinary Services (2019)

Incapability to meet domestic demand remains as the main problem in beef industry. The slow growth rate of production of domestic cattle and buffalo in relation to the growth rate of its product demand still exists even after great interventions by Malaysia government. Low rates of multiplication and low effects of imported breeding animal caused the population base for beef animal to still be considered small. Since the supply could not meet the demand, beef industry in Malaysia has to depend on imports especially the imports of frozen and chilled beef. For the past forty years, more than $70 \%$ of beef requirement are supported by import of frozen and chilled beef. This type of import depresses the demand for 
local beef as the price of imported beef is generally cheaper. The production of local beef is discouraged because of this stiff competition.

Previously, beef policy simulation in Peninsular Malaysia had been done by Mohamed, Hosseini \& Kamarulzaman (2013) and Ibragimov et al. (2016). Mohamed, Hosseini \& Kamarulzaman (2013) analyse the policy using Vintage approach simulation matrix model, while Ibragimov et al. (2016) use system dynamic approach for the analysis. Both of these studies did not apply robust econometric approach in developing the model. For the past 30 years there were three econometric analyses on beef industry in Peninsular Malaysia - by Mohd Jani, Jaafar \& Senteri, (1989), Mohd Jani \& Ibrahim (1993) and Sarmin (1998). However, these studies did not proceed with policy simulation analysis.

For livestock commodities, the behavioural nature of the relationships between the major variables in the industries of interest have to be taken into account (Vere \& Griffith, 2003). Vere, Griffith \& Bootle (1993) suggest that changes in inventory are independent of economic influences but primarily determined by biological lags. Other studies that also include own lags population as the explanatory for cattle inventory are Tryfos (1974), Rucker, Burt, \& LaFrance (1984), Lianos \& Katranidis (1993), and Buhr (1993).

On the demand side, demand for beef may be sensitive to its own price. Previous studies provide different findings on this topic. For example, Baharumshah (1993), Baharumshah \& Mohamed (1993) and Mohamed \& Abdullahi (2004) have found that price elasticity of demand for beef to be inelastic, indicating that consumers are not sensitive to price change. Meanwhile, Mohd Jani \& Ibrahim (1993) and Tey et al. (2010), have found that the price elasticity of demand for beef is more than 1 , which means consumers are sensitive to price change. Previous studies have also stated that poultry meat is the most common substitute for beef (Mohamed \& Roslan, 1989; Baharumshah, 1993; Baharumshah \& Mohamed, 1993; Mohd Jani, Jaafar \& Senteri, 1989; Mohd Jani \& Ibrahim, 1993; Tey et al., 2010). With respect to income, it was reported that demand for beef is not sensitive to income (Baharumshah, 1993; Baharumshah \& Mohamed, 1993; Mohd Jani \& Ibrahim, 1993; Tey et al., 2010).

In brief, the purpose of this study is to identify factors affecting beef production and demand in Peninsular Malaysia. The aims are to explain how breeding inventory affecting the supply of beef cattle for slaughter and to describe the expenditure of beef in Peninsular Malaysia meat market. This study provides elasticities for both supply and demand side of Peninsular Malaysia's beef industry. Then it analyses the impacts of different importation policy scenarios on beef industry in Peninsular Malaysia.

\section{RESEARCH METHOD}

For this study, a market model was utilized to perform the policy analysis. Econometric approach was used to estimate the market model. The construction of market model begins with specifying the model structure and economic relationships before estimating the parameters from historical data (Labys \& Pollak, 1984). To construct the framework in this 
study, the basic structure of a market model by Labys (1973) is used. The basic structure of the market model was as the followings.

Supply, $S_{t}=f\left(P O_{t}, P S_{t}, N_{t}, Z S_{t}\right)$

Demand, $D_{t}=f\left(P O_{t}, P S_{t}, Y_{t}, Z D_{t}\right)$

Stock, $I_{t}=I_{t-1}+S_{t}-D_{t}$

where, $P O_{t}$ was price of the commodity in time $t, P S_{t}$ was price of other commodity in time t (competitor), $N_{t}$ was natural factors in time $t, Y_{t}$ was income in time t, $Z S_{t}$ was other supply shifters in time $t$, and $Z D_{t}$ was other demand shifters in time $t$.

The structure of beef industry model in this study is almost similar to the model used by Mohd Jani \& Ibrahim (1993) and Sarmin (1998). The difference is that in this model, price is not a determinant for beef cattle inventory. The beef cattle inventory which depends on breeding decision may be expected to be responsive to changes in price. However, Vere, Griffith, \& Bootle, (1993) suggest that changes in inventory are independent of economic influences but primarily determined by biological lags. Therefore, in this model, the beef cattle inventory is mainly determined by its own lags and other categories of sex and age. The specific framework of beef industry is presented in Figure 1.

Annual time series data from 1970 to 2015 were used for the beef industry model. Most of the data especially the livestock population are from various issues of Livestock Statistic and Population \& Slaughter of Livestock published by Department of Veterinary Services. Retail price of livestock commodities are obtained from various issues of Warta Barangan published by Federal Agricultural Marketing Authority (FAMA). The estimation technique used in this study is two-stage least squares (2SLS) regression as system of equations. The estimated data are transformed into log before being estimated.

The beef industry policy simulation is conducted based of Malaysian Agricultural Policy Analysis (MAgPA) model framework. MAgPA is a multi-commodity forecasting and policy simulation model for Malaysian agricultural sector (Fatimah et al., 2012a; Fatimah et al., 2012b). Once the beef industry model is estimated, the coefficient or elasticities are inputted into MAgPA. In order to analyse the beef industry policy simulation, the rate of changes of import of cattle for breeding (ICTB) and import of cattle for slaughter or feeder cattle (ICTS) are set.

Three different scenarios are defined; scenario 1, scenario 2 and scenario 3. Scenario 1 assumes that the beef industry grows at current rates of $10 \%$ for ICTB and $15 \%$ for ICTS. Scenario 2 tries to analyse the effects of increasing the ICTB while maintaining the number of ICTS. The rate of changes for ICTB is $20 \%$ and ICTS is $0 \%$. This scenario reflects the intention of improving the population base of the beef cattle rather than investing more on foreign supply of beef cattle for their meat. The focus of this policy is more on increasing the breeding activities. Scenario 3, on the other hand, examines the effects of importing more cattle for slaughter or feeder cattle as the rate of changes of ICTS is set at $20 \%$ while ICTB is set at $0 \%$. This scenario reflects the intention of supplying more fresh beef to the domestic market in order to reduce the dependency on import of frozen and chilled beef. The investment on breeding animal are maintain as it is. 


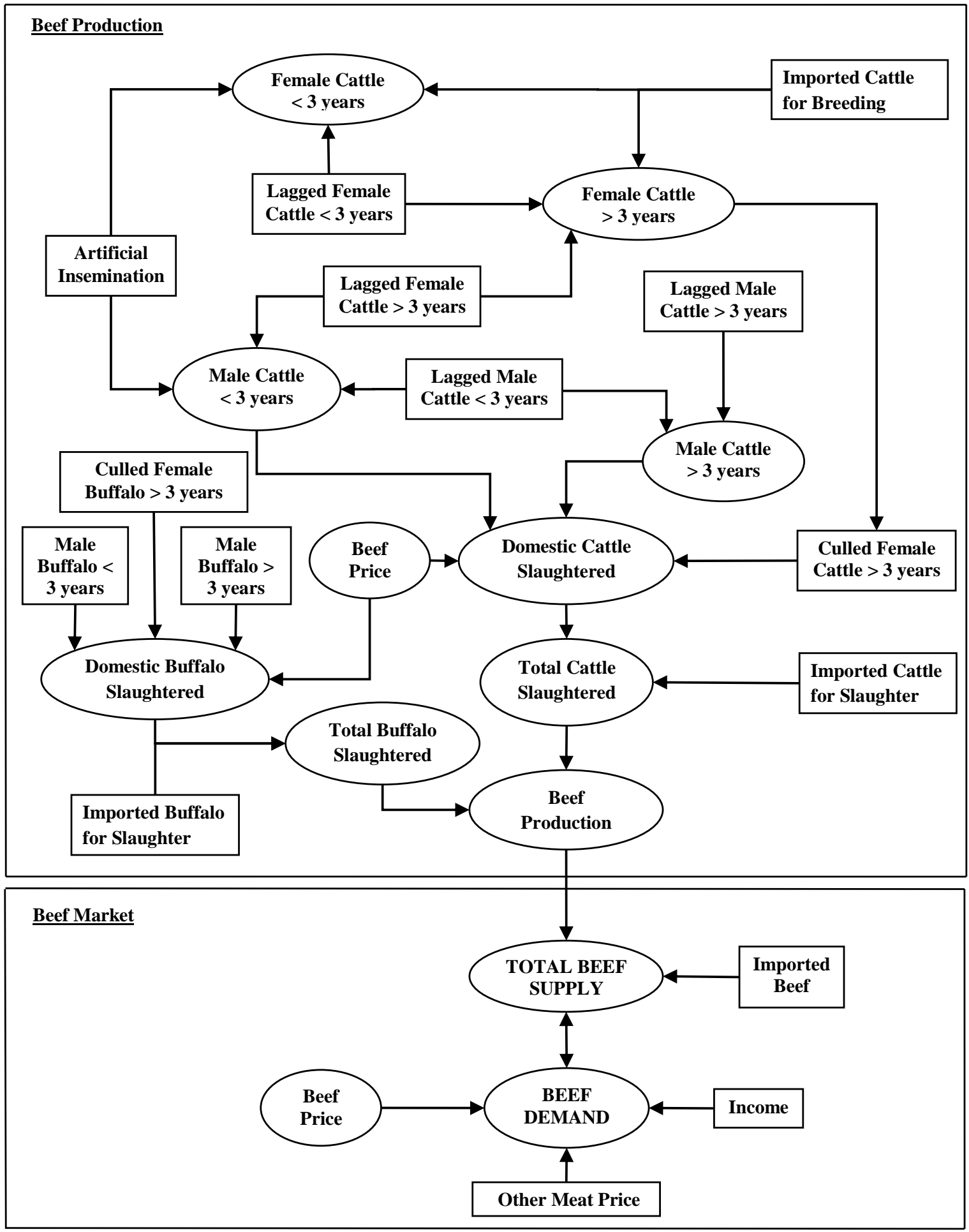

Legend:

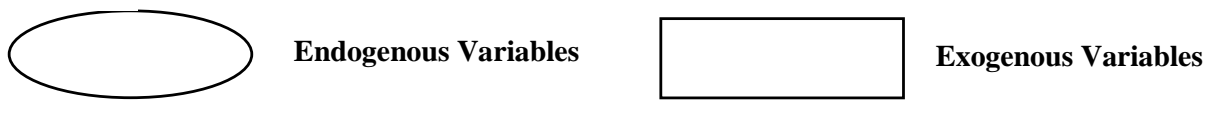

FIGURE 1. SPECIFIC DIAGRAM OF BEEF INDUSTRY IN PENINSULAR MALAYSIA (MODIFIED FROM MOHD JANI \& IBRAHIM, 1993, SARMIN, 1998, AND VERE \& GRIFFITH, 2003) 


\section{RESULT AND DISCUSSIONS}

The estimated beef industry model in Table 5, 6 and 7 indicate that there are significant relationship between the dependent variables and the independent variables. The signs of the estimated independent variables are consistent with the priori expectation. In term of R2, the estimates are quite satisfactory. Jarque-Bera statistic shows that the residuals for each equation are normally distributed. Breusch-Godfrey Lagrange multipliers (BGLM) and Durbin-Watson tests indicate that there is no autocorrelation bias appears in the estimation.

TABLE 5. ESTIMATED EQUATIONS OF BEEF CATIE INVENTORY

\begin{tabular}{|c|c|c|c|c|}
\hline \multicolumn{5}{|c|}{ Female Catle Above 3 Years } \\
\hline \multirow[t]{4}{*}{$\begin{array}{r}\text { FCA3 }=2.5389 \\
{[3.3636]^{* *}}\end{array}$} & $\begin{array}{c}+0.0020 \text { ICTB } \\
* 0.3240] \\
\end{array}$ & $\begin{array}{c}+0.1964 \text { FCB3-1 } \\
{[2.6958]^{* * *}}\end{array}$ & $\begin{array}{c}+0.5594 \text { FCA3-1 } \\
{[3.3654]^{* * *}} \\
\end{array}$ & $\begin{array}{ll}+ & 0.0355 \text { FCA3-2 } \\
& {[0.2244]} \\
\end{array}$ \\
\hline & Adjusted R-squared & 0.9511 & Jarque-Bera & 3.2684 \\
\hline & F-statistic & 180.7467 & $B G L M \chi^{2}(2)$ & 3.7872 \\
\hline & & & Durbin-Watson & 1.9883 \\
\hline \multicolumn{5}{|c|}{ Female Cattle Below 3 Years } \\
\hline \multirow{4}{*}{$\begin{array}{r}\text { FCB3 }=0.5411 \\
{[1.7535]^{*}}\end{array}$} & $\begin{array}{c}+0.0010 \text { ICTB } \\
{[0.1529]}\end{array}$ & $\begin{array}{c}+0.0065 \text { AlBA- } 1 \\
{[0.8422]}\end{array}$ & $\begin{array}{c}+0.9515 \text { FCB3- } 1 \\
{[24.6028]^{* * *}}\end{array}$ & \\
\hline & Adjusted R-squared & 0.9766 & Jarque-Bera & 0.2675 \\
\hline & F-statistic & 514.8010 & $B G L M \chi^{2}(2)$ & 1.2194 \\
\hline & & & Durbin-Watson & 2.3232 \\
\hline \multicolumn{5}{|c|}{ Male Cattle Below 3 Years } \\
\hline \multirow{5}{*}{$\begin{aligned} \text { MCB3 }= & 11.4456 \\
& {[4.9444]^{* * *} }\end{aligned}$} & +0.0602 AlBA-1 & +0.0488 FCA3-1 & +0.9693 MCB3-1 & \\
\hline & ${ }^{*} \quad[0.6686]$ & [0.2738] & {$[35.9287]^{* * *}$} & \\
\hline & Adjusted R-squared & 0.9788 & Jarque-Bera & 0.3279 \\
\hline & F-statistic & 569.1498 & $B G L M \chi^{2}(2)$ & 3.7811 \\
\hline & & & Durbin-Watson & 2.2434 \\
\hline \multicolumn{5}{|c|}{ Male Cattle Above 3 Years } \\
\hline \multirow{5}{*}{$\begin{aligned} \mathrm{MCA}= & 2.4073 \\
& {[2.6181]^{* * *} }\end{aligned}$} & +0.1482 MCB3-1 & +0.6187 MCA3-1 & & \\
\hline & $* \quad[2.3762]^{* *}$ & {$[4.5362]^{* * *}$} & & \\
\hline & Adjusted R-squared & 0.8268 & Jarque-Bera & 2.7459 \\
\hline & F-statistic & 89.2861 & $B G L M \chi^{2}(2)$ & 2.0776 \\
\hline & & & Durbin-Watson & 1.6960 \\
\hline
\end{tabular}

Note: Numbers in parentheses [ ] are t-values. ${ }^{* * *},{ }^{* *}$, and ${ }^{*}$ denote as significant at $1 \%, 5 \%$, and $10 \%$ significance level.

The estimated equations of beef cattle inventory are presented in Table 5. In female cattle above 3 years (FCA3) and female cattle below 3 years (FCB3) equations, one-year lagged of their own population are significance at 1\% level. One-year lagged FCB3 also appears to be significance in FCA3 equations. The results suggest the importance of FCB3 in the development of FCA3. Retaining female cattle for longer period in beef cattle farming will increase breeding cattle population. Young female cattle are strictly retained for breeding purposes. In cattle breeding also, beef cattle operators need to explore more on artificial insemination (AIBA) and imported cattle for breeding (ICTB). The elasticities of FCA3 with respect to imported cattle for breeding (ICTB), FCB3-1, FCA3-1, and FCA3-2 are 0.0020, 
elasticity between DSBFS and three-year lagged FBA3 is 0.4098 . The contribution of male buffalo to supply of beef animal for slaughter is insignificant because buffalo population has been shrinking since mid-1960s due to technological advancement in paddy farming (Mohd Jani \& Ibrahim, 1993). Therefore, the elasticity of DSBFS with respect to male buffalo above 3 Years (MBA3) and male buffalo below 3 years (MBA3) are only 0.1536 and 0.1641 respectively. DSBFS also does not respond to price as the elasticity between DSBFS and RPB is only 0.0253 .

The estimated equations of beef demand are presented in Table 7. Beef consumption per capita (CPCB) is significantly determined by own price of beef (RPB) and income per capita (GDPPC) at 10\% and 1\% level respectively. Own price elasticity is negative which is a priori to demand theory. Increase in RPB by $1 \%$ will result in a $0.5651 \%$ decrease in CPCB. This result is consistent with the findings by Baharumshah (1993), Baharumshah \& Mohamed (1993) and Mohamed \& Abdullahi (2004) which indicates that price elasticity of demand for beef is inelastic. The elasticity of CPCB with respect to GDP per capita (GDPPC) is elastic at 1.1573 , indicating that $1 \%$ increase in GDPPC will increase CPCB by $1.1573 \%$. The elasticities of CPCB with respect to price for chicken meat (RPC) and price for fish (RPF) are 0.2090 and 0.1089 respectively. Chicken meat and fish are substitute products for beef.

TABLE 7. ESTIMATED EQUATIONS OF BEEF DEMAND

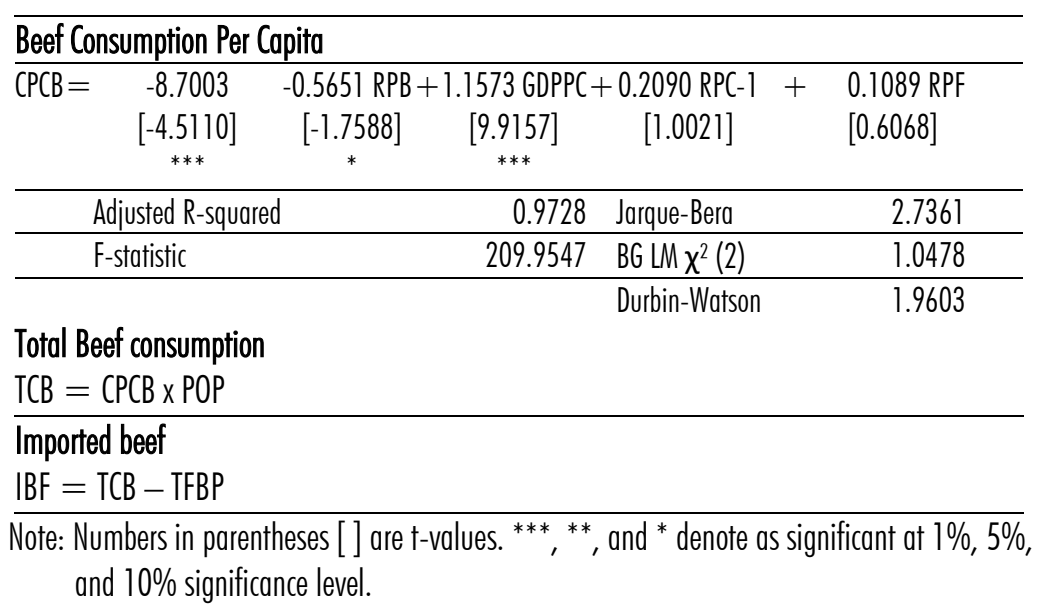

For beef industry policy simulation, beef production is projected to increase from 46,938 MT in 2011 to 96,472 MT in 2020 under scenario 1. This increase is caused by domestic cattle slaughtered which are projected to increase by an average of $0.38 \%$ annually. Domestic buffalo slaughtered are projected to decrease by an average of $0.25 \%$ annually. On the other side, beef consumption is also projected to increase from 164,578 MT to 263,911 MT during the same period. Beef consumption per capita is projected to increase from 7.11 $\mathrm{kg}$ to $9.46 \mathrm{~kg}$. Beef self-sufficiency level increase from $28.52 \%$ in 2011 to $36.55 \%$ in 2020. Although the beef self-sufficiency level increases, beef import is still projected to increase by an average of $4.00 \%$ annually during the same period in order to stabilize the beef price. During the period of 2011 to 2020 , beef retail price is projected to increase from RM19.15 to RM26.78. 
Under scenario 2, there is only a slight increase in beef production (TFBP) from 44,543 MT in 2011 to 45,798 MT in 2020. This is mainly due to the characteristic of beef production which depends much on imports of feeder cattle or cattle for slaughter. Although there are domestic cattle slaughtered (DSCFS), it still has a limit because not all domestic cattle can be slaughtered. This can be seen in the small growth rate of domestic cattle slaughtered at $0.56 \%$. As for domestic buffalo slaughtered, it keeps on decreasing from 11,147 heads in 2011 to 10,376 heads in 2020. On the demand side, beef consumption per capita (CPCB) increases from $7.01 \mathrm{~kg}$ to $8.15 \mathrm{~kg}$ during the same period. As the population grows, total beef consumption (TCB) increases from 162,183 MT to 227,417 MT. Because of this rapid growth in beef consumption and only slightly increment in beef production, beef self-sufficiency level decreases from $27.46 \%$ to $20.14 \%$ during the same period. To fulfil domestic demand for beef, beef import grows annually at $4.86 \%$ rate during the same period. Beef retail price increases drastically from RM19.62 to RM35.15.

Lastly, beef production (TFBP) under scenario 3 is projected to increase drastically from $47,728 \mathrm{MT}$ in 2011 to $131,849 \mathrm{MT}$ in 2020. The effect of such growth causes a slight increase in beef retail price, from RM19.00 to RM21.39. When the supply side of beef industry drastically increases, the demand side will also increase due substitutability effect as beef is substituted for mutton and chicken meat. Consumer shifts to beef because beef retail price is declining in real term. Beef consumption increases from 165,368 MT in 2011 to 299,289 MT in 2020 . Beef self-sufficiency level also increases from $28.86 \%$ to $44.05 \%$ during the same period.

\section{CONCLUSIONS}

Based on the estimated beef industry model, it can be said that the beef cattle population is still far from being able to supply sufficient amount of animal for slaughter because of low performance in breeding activities. This can be seen through the equations in the beef cattle inventory block. In beef cattle inventory block, beef cattle population are highly influenced by the population of its own lagged. Female cattle are the most important component in beef industry. The elasticity of FCB3-1 in FCA equation (0.1964) suggests that the mortality rate or death loss from female cattle is quite high as the elasticity is considered small. While the elasticity of FCA3-1 in MCB equation (0.0488) indicates the female cattle do not perform well in breeding activities. The productivity (in term of producing calf) needs to be continuously improved in order to increase the calving rate. The good sign in beef industry is that producers tend to hold female breeders for longer period as shown by the elasticity of FCA3-3 in slaughter equation.

Meanwhile, on the demand side, income elasticity of demand for beef is elastic, indicating that a $1 \%$ increase in income per capita (GDPPC) will increase beef consumption per capita by $1.1573 \%$. The substitutability of chicken meat and fish are not elastic as the elasticities of chicken meat price and fish price with respect to beef demand are only 0.2090 and 0.1089 respectively. 
From the estimation of beef industry equations, it can be summarized that death loss from female cattle contributes to low productivity of beef cattle. Meanwhile, from the beef industry policy simulation, it can be seen that fresh beef supply significantly depend on import of cattle for slaughter or feeder cattle.

To conclude, Malaysia can still improve the beef self-sufficiency level. The importation policy of breeder cattle should be improved on the quality such as low mortality rate and high yield. If this could be done, in the long run, breeding activities could be improved and consequently the multiplication rate of beef cattle could be increased. At the same time, the government has to deal with the increasing demand for beef through increasing the supply of fresh beef by continue importing cattle for slaughter or feeder cattle. This will help to stabilize the price of beef as the price of beef not only affects the beef industry, but could affect the supply and demand for other meats.

\section{ACKNOWLEDGEMENTS}

This work was supported by Department of Agribusiness and Bioresource Economics, Faculty of Agriculture and Institute of Agricultural and Food Policy Studies, Universiti Putra Malaysia.

\section{REFERENCES}

Baharumshah, A.Z. \& Mohamed, Z. (1993). Demand for meat in Malaysia: An Application of the Almost Ideal Demand System Analysis. Pertanika J.Soc.Sci.Ë Hum, 1(1), 91-99.

Baharumshah, A.Z. (1993). Applying the Almost Ideal Demand Systems to Meat Expenditure Data: Estimation and Specification Issues. The Malaysian Journal of Agricultural Economics, $10,23-37$.

Buhr, B.L. (1993). A Quarterly Econometric Simulation Model of the U.S. Livestock and Meat Sector. Staff Paper Series P93-12, University of Minnesota, Minnesota.

Department of Veterinary Sevices. (1970-1998). Livestock Statisitic 1970-1998. Department of Veterinary Services, Malaysia.

Department of Veterinary Sevices. (1999-2009). Population EF Slaughter of Livestock 1999-2009. Department of Veterinary Services, Malaysia.

Department of Veterinary Sevices official website, http://www.dvs.gov.my [accessed on 5 February 2011]

Department of Veterinary Sevices official website, http://www.dvs.gov.my [accessed on 17 September 2012]

Department of Veterinary Services official website, http://www.dvs.gov.my [accessed on 18 July 2019]

Fatimah et al.. (2012a). Malaysian Agricultural Policy Analysis Model (MAgPA) Volume I: Commodity Market Models, final report submitted to Economic Planning Unit (EPU), Prime Minister Department, Malaysia, 527 pp.

Fatimah et al.. (2012b). Malaysian Agricultural Policy Analysis Model (MAgPA) Volume II: Agricultural Sector Model, final report submitted to Economic Planning Unit (EPU), Prime Minister Department, Malaysia, 484 pp. 
Ibragimov, A., Mohamed Arshad, F., Bala, B. K., Bach, N. L. \& Mohammadi, S. (2016). Management of Beef Cattle Production in Malaysia: A Step Forward to Sustainability. American Journal of Applied Sciences, 13(9), 976-983.

Labys, W.C. (1973). Dynamic Commodity Models: Specifications, Estimation and Simulation. Massachusettes: Lexington.

Labys, W.C., \& Pollak, P.K. (1984). Commodity Models for Forecasting and Policy Analysis. New York: Nicholas Publishing Company.

Lianos, T.P., \& Katranidis, S. (1993). Modelling the Beef Market of the Greek Economy. European Review of Agricultural Economics, 20, 49-63.

Mohamed, Z. \& Abdullahi F.A. (2004). Alternative Estimation of Meat Supply and Demand in Peninsular Malaysia's Beef Sector: An Application of Cointegration and Error Correction Model Techniques. Proceedings of Agriculture Congress: Innovation Towards Modernized Agriculture, Kuala Lumpur, Malaysia.

Mohamed, Z., Hosseini, A., \& Kamarulzaman, N. H. (2013). Analysis of Malaysian Beef Industry in Peninsular Malaysia under Different Importation Policies Scenarios and Rate Management Systems. Pertanika J Soc Sci \& Hum, 21(S), 1-16.

Mohamed, Z. \& Roslan, A.B. (1989). Estimating the Income and Substitution Effects on the Demand for Poultry Meat. Pertanika, 12(1), 119-123.

Mohd Jani, M. F., \& Ibrahim, Y. (1993). An Econometric Analysis of the Beef Market in Peninsular Malaysia. In F. Mohd Arshad, M.N. Shamsudin, \& M.S. Othman (Eds), Malaysian Agricultural Commodity Forecasting and Policy Modelling (pp. 101-120). Malaysia: Centre for Agriculture Policy Studies (CAPS), Universiti Pertanian Malaysia.

Mohd Jani, M. F., Jaafar, A. H. \& Senteri, Z. (1989). An Econometric Analysis of the Supply and Demand of Beef in Peninsular Malaysia. Jurnal Ekonomi Malaysia, 19, 31-46.

Rucker, R.R., Burt, O.R., \& LaFrance, T. (1984). An Econometric Model of Cattle Inventories. American Journal of Agricultural Economics, 66(2), 131-144.

Sarmin, S. (1998). An Econometric Analysis of the Peninsular Malaysia Beef Market. Unpublished Master's Thesis, Universiti Putra Malaysia, Serdang.

Tey, Y.S., Shamsudin, M.N., Mohamed, Z., Amin, M.A., \& Radam, A. (2010). Demand Analysis of Meat in Malaysia. Journal of Food Products Marketing, 16, 199-211.

Tryfos, P. (1974). Canadian Supply Functions for Livestock and Meat. American Journal of Agricultural EO Applied Economics, 56(1), 107-113.

Vere, D.T., \& Griffith, G.R. (2003). Structural Econometric Modelling in Australia's Livestock Production and Marketing Systems: The Potential Benefit of Model Integration for Industry Analysis. Agricultural System, 81, 155-131.

Vere, D.T., Griffith, G.R., \& Bootle, B.W. (1993). Alternative Breeding Inventory Specifications in a Livestock Market Model. Australian Journal of Agricultural Economics, 37(3), 181-204. 